\title{
Physicochemical and Nutritional Evaluation of Bread Incorporated with Ayocote Bean (Phaseolus coccineus) and Black Bean (Phaseolus vulgaris)
}

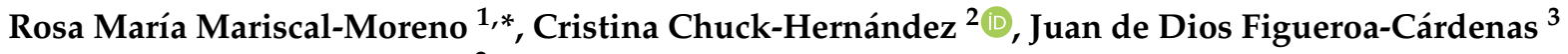 \\ and Sergio O. Serna-Saldivar ${ }^{2}$ \\ 1 Universidad Iberoamericana Ciudad de México, Health Department, Prolongación Paseo de la \\ Reforma 880, Col. Lomas de Santa Fe, Álvaro Obregón, Mexico City 01219, Mexico \\ 2 Tecnologico de Monterrey, School of Engineering and Sciences, Av. Eugenio Garza Sada 2501, \\ Monterrey 64849, Mexico; cristina.chuck@tec.mx (C.C.-H.); sserna@tec.mx (S.O.S.-S.) \\ 3 CINVESTAV-Unidad Querétaro, Libramiento Norponiente No. 2000, Fraccionamiento Real de Juriquilla, \\ Querétaro 76230, Mexico; jfigueroa@cinvestav.mx \\ * Correspondence: rosa.mariscal@ibero.mx; Tel.: +52-1-442-1057986
}

Citation: Mariscal-Moreno, R.M.; Chuck-Hernández, C.; Figueroa-Cárdenas, J.d.D.; Serna-Saldivar, S.O. Physicochemical and Nutritional Evaluation of Bread Incorporated with Ayocote Bean (Phaseolus coccineus) and Black Bean (Phaseolus vulgaris). Processes 2021, 9 , 1782. https://doi.org/10.3390/ pr9101782

Academic Editors: Yonghui Li and Shawn (Xiaorong) Wu

Received: 31 August 2021

Accepted: 24 September 2021

Published: 6 October 2021

Publisher's Note: MDPI stays neutral with regard to jurisdictional claims in published maps and institutional affiliations.

Copyright: (c) 2021 by the authors. Licensee MDPI, Basel, Switzerland. This article is an open access article distributed under the terms and conditions of the Creative Commons Attribution (CC BY) license (https:// creativecommons.org/licenses/by/ $4.0 /)$.

\begin{abstract}
The objective of this study was to examine the physicochemical composition, thermal properties, quality, and sensorial characteristics of bread with substitution of wheat flour with ayocote bean (Phaseolus coccineus) or black bean (Phaseolus vulgaris) flours at 10, 20, and 30\%. Ayocote and black bean contain 21.06 and $23.94 \%$ of protein, 3.06 and $5.21 \%$ of crude fiber, and 3.1 and $5.21 \%$ of ash, respectively, directly influencing bread composition. Bread with ayocote and black bean presented higher values in those components in contrast with control bread. The protein content increased in a range of $14-34 \%$; ash increased by $10 \%$ to double, and crude fiber also increased. In vitro protein digestibility was similar for bread with $10 \%$ of substitution and control, and it decreased in samples with $30 \%$ of wheat substitution. Thermal analysis by DSC denoted that the addition of those legumes reduces retrogradation, as seen in $45.33-65.65{ }^{\circ} \mathrm{C}$ endotherm, producing higher endotherms of amylose-lipid complexes and protein denaturalization. Finally, the addition of black bean and ayocote bean decreased specific volume when the replacement percentage was 30\% black bean and 20 and 30\% for ayocote. An increase in nutrient content without sensorial properties affectation could be observed in substitution around 10 and $20 \%$.
\end{abstract}

Keywords: ayocote bean; black bean; bread; protein digestibility; sensorial properties

\section{Introduction}

Bread is a dietary staple in human nutrition. Research on bread is globally conducted to improve its nutritional value (macronutrients: carbohydrates, proteins, fat, and dietary fibers; micronutrients: minerals and vitamins), health-supporting bioactive compounds, sensory acceptability, shelf life, and affordability [1], additionally, some studies have focused on provide options to celiatics individuals. Several studies have shown that vegetable-based products contain a significant amount of nutrients (proteins, vitamins and minerals) as well as functional and bioactive compounds and that in this context bread enrichment with non-cereal flours could have a positive effect on their nutritional value [2,3] The possibility of bread enrichment with legumes facilitates increased consumption in the home and adaptation to social, economic, and cultural changes. Research concerning new alternative plant protein sources is mostly focused on legumes [4]. Legumes are of interest to food technologists and the food industry due to their functionality, nutritional characteristics, and protein content. Some underutilized legumes are locally consumed, despite having high potential as a source of bioactive compounds and health-promoting food. Ayocote bean (Phaseolus coccineus L.) is a native legume from the Mexican highlands. It is a 
poorly studied species, despite its importance for human feeding and its potential for breeding because of its disease resistance and against some abiotic factors as cold tolerance [5]. Ayocote has been found to be a promising source of proteins $(185.3 \mathrm{mg} / \mathrm{kg})$, carbohydrates $(677.6 \mathrm{mg} / \mathrm{kg})$, fiber $(67.4 \mathrm{mg} / \mathrm{kg})$ and minerals. Glutamatic acid was the most abundant amino acid (32.2 to $35.8 \mathrm{~g} / \mathrm{kg}$ ). The purple variety contains the highest amount of total phenolic compounds (2075.9 mg GAE/ kg), total flavonoids $(1612.9 \mathrm{mg} \mathrm{QE} / \mathrm{kg}$ ) and total anthocyanins (1193.2 $\mathrm{mg}$ CGE/kg) [6].

Additionally, the common bean (Phaseolus vulgaris L.) is the most important food legume used for direct consumption worldwide. Compared with other food crops, it has one of the widest ranges of variation in growth habits, seed characteristics (size, shape, and color), maturation times, and adaptation [7]. Bean proteins are rich in lysine, being an excellent complement to cereal proteins such as rice or corn, which are deficient in this amino acid [8]. And those legumes are adequate sources of complex carbohydrates, usually the predominant fraction is starch (50-60 g/100 g) and dietary fiber [9]. More importantly, the starch has slow digestion properties mainly attributed to the amylose content of beans have been cataloged as low-medium GI foods [10]. Recently, the bioactive compounds associated to beans, mainly constituted by saponins and flavonoids, have shown potential to prevent chronic diseases and cancer [11].

The food industry is interested in the development on cereal products with higher nutritional value. This work investigates the effects of the substitution of wheat flour by ayocote and black bean ( $\mathrm{AB}$ and $\mathrm{BB}$, respectively) in bread production on the thermal properties of composite flours, the bread's proximal composition, in vitro protein digestibility (IPD) as well as color and sensorial parameters of the final products. This use coul figure as an alternative application for underutilized legumes.

\section{Materials and Methods}

\subsection{Ayocote Beans and Black Beans}

Commercial grade wheat bread flour was used in this study (brand: San Antonio ${ }^{\circledR}$, Tres estrellas, Toluca, México). The wheat flour had a proximal composition of $12.78 \%$ of protein and $13.87 \%$ of moisture. A commercial dry yeast (Saccharomyces cerevisiae) was used (Tradi-Pan ${ }^{\circledR}$, Lesaffre, Toluca, México).

One variety of purple ayocote beans $(\mathrm{AB})$ and one black bean $(\mathrm{BB})$ were assayed in the present study. Both were purchased from a local market in Actopan, Hidalgo, México. Physical dimension of beans, namely length, width and thickness were measured for 50 seeds using a digital Vernier caliper with an accuracy of $0.01 \mathrm{~mm}$. BB seeds measured $1.06 \pm 0.05 \mathrm{~cm}$ (length), $0.6 \pm 0.06 \mathrm{~cm}$ (width) and $0.43 \pm 0.05 \mathrm{~cm}$ (thickness). AB measured $1.76 \pm 0.06 \mathrm{~cm}$ (length), $1.16 \pm 0.06 \mathrm{~cm}$ (width) and $0.80 \pm 0.10 \mathrm{~cm}$ (thickness). Seeds were ground using a $900 \mathrm{~W}$ Nutribullet ${ }^{\circledR}$ blender (Nutribullet, Los Ángeles, CA, USA) to obtain flour. It was then sieved through a 40 US mesh until all portions passed and was stored at room temperature in polyethylene bags until analysis.

\subsection{Flour and Bread Preparation}

Four wheat-legume flour mixtures were prepared with 0, 10, 20, and 30\% (total flour weight basis) for each bean. Flours were mixed for $3 \mathrm{~min}$, and bread were elaborated accordingly with Yeh et al. [12] with slight modifications: double of yeast was added, and butter was replaced for vegetable oil ( $8 \mathrm{~g} / 100 \mathrm{~g}$ of flour). Bread formulation is presented in Table 1 for each sample. The ingredients were mixed for $5 \mathrm{~min}$, in a blender (Kitchen Aid, Mod K5SSWH, Wirlpool, Apodaca, NL, México) equipped with a spiral hook blade. The same method was applied for all samples. Fermentation was done in a fermentation cabinet at $25^{\circ} \mathrm{C}$ with $60 \% \mathrm{RH}, 10 \mathrm{~min}$. Next, the dough (100 g) was again kneaded for $10 \mathrm{~min}$ and put in a greased mold $(23.11 \mathrm{~cm} \times 9.9 \mathrm{~cm} \times 6.1 \mathrm{~cm})$ for bread, increasing its volume for $20 \mathrm{~min}$. Afterward, doughs were simultaneously baked in a pre-heated oven (Mod. HSPU, Sanson, Naucalpan, Edo de Mex, México) at $200{ }^{\circ} \mathrm{C}$, for $15 \mathrm{~min}$. After baking, the bread was cooled down to room temperature $1 \mathrm{~h}$ and then they were stored 
in polyethylene bags for $24 \mathrm{~h}$ and subsequently cut into slices $(1.27 \mathrm{~cm}$ thick) using an electric knife (type EK08, Hamilton Beach, Mexico City, CDMX, México). Slices were used for sensorial analysis one day after baking and other slices were dried at room temperature until moisture around $12 \%$ and were milled for further analysis.

Table 1. Formula (in baker's percent) of breads added with black bean and ayocote bean.

\begin{tabular}{|c|c|c|c|c|c|c|c|}
\hline \multirow[t]{2}{*}{ Ingredients } & \multirow[t]{2}{*}{ Control Bread } & \multicolumn{4}{|c|}{ Bread with Black Bean } & \multicolumn{2}{|c|}{ Bread with Ayocote Bean } \\
\hline & & 10 & 20 & 30 & 10 & 20 & 30 \\
\hline Wheat flour & 100 & 90 & 80 & 70 & 90 & 80 & 70 \\
\hline Ayocote flour & - & 10 & 20 & 30 & - & - & - \\
\hline Black bean flour & - & - & - & - & 10 & 20 & 30 \\
\hline Yeast & 1 & 1 & 1 & 1 & 1 & 1 & 1 \\
\hline Milk power & 4 & 4 & 4 & 4 & 4 & 4 & 4 \\
\hline Sugar & 8 & 8 & 8 & 8 & 8 & 8 & 8 \\
\hline Salt & 1.5 & 1.5 & 1.5 & 1.5 & 1.5 & 1.5 & 1.5 \\
\hline Water & 63 & 63 & 63 & 63 & 63 & 63 & 63 \\
\hline Butter & 4 & 4 & 4 & 4 & 4 & 4 & 4 \\
\hline
\end{tabular}

\subsection{Proximal Analysis}

Chemical characterization was made in flours and bread samples, following official methods: moisture, ash, protein, crude fat, and fiber according to AACC 44-15.02, 08-01.01, 46-13.01, 30-25.01, and 32-10.01, respectively (AACC 2000). Carbohydrates were determined by difference [100 - (crude protein + crude fat + ash + crude fiber)].

The nutritional value of protein bread was calculated using conversion factors according to EU Regulation No 1169/2011 [11] on the provision of food information to consumers: (1) Carbohydrates (except polyols): $4 \mathrm{kcal} \cdot \mathrm{g}^{-1}$; (2) Protein, $4 \mathrm{kcal} \cdot \mathrm{g}^{-1}$; (3) Fat, $9 \mathrm{kcal} \cdot \mathrm{g}^{-1}$; (4) Fiber, $2 \mathrm{kcal} \cdot \mathrm{g}^{-1}$

\subsection{Thermal Properties of Bread Incorporated with Black Bean and Ayocote Bean}

Before carrying the thermal analysis, breads were dried at $40{ }^{\circ} \mathrm{C}$ for $72 \mathrm{~h}$ until the moisture ranged from $12.5-12.0 \%$, three hours post-baking. Then they were milled and sieved through a 60 US mesh until all samples passed the mesh. This process was done in triplicate for each sample. Thermal analyses were conducted as reported by SantiagoRamos et al. [13] using a differential scanning calorimeter (DSC1 model 821, Mettler Toledo, Greifensee, Switzerland) previously calibrated with indium. Five milligrams of the sample were weighed in an aluminum pan, and deionized water was added until the moisture content reached $60 \%$, using an empty aluminum pan as a reference. The sample was heated from 30 to $130{ }^{\circ} \mathrm{C}$ at a rate of $10^{\circ} \mathrm{C} \mathrm{min}{ }^{-1}$. Transition endotherms were characterized by their onset, peak, and final transition temperatures and enthalpy change. Each treatment was analyzed in triplicate.

\subsection{In Vitro Protein Digestibility (IPD)}

This determination was assessed with the procedure reported by Hsu et al. 1977 [14], briefly described: a $50 \mathrm{~mL}$ quantity of protein suspension of $6.25 \mathrm{mg} / \mathrm{mL}$ of protein was prepared and adjusted to $\mathrm{pH} 8$. The protein suspension was prepared with dry bread adjusting weights accordingly with protein bread content. As was described previously, bread samples were dried, grinding and subsequently sieved with a 40 US mesh until the complete sample passed. Separately, a multi-enzymatic solution was prepared by mixing trypsin $(1.6 \mathrm{mg} / \mathrm{mL})$, chymotrypsin $(3.1 \mathrm{mg} / \mathrm{mL})$, and S. griseus protease $(1.3 \mathrm{mg} / \mathrm{mL})$. The protein solution was maintained in agitation, and $5 \mathrm{~mL}$ of the multi-enzymatic solution was added. The $\mathrm{pH}$ drop was recorded over a $10 \mathrm{~min}$ period using a potentiometer previously calibrated with standard $\mathrm{pH}$ solutions. Enzymes used were porcine pancreatic trypsin type IX-S (T4799, Sigma Aldrich, Burlington, MA, USA), bovine pancreatic chymotrypsin type 
II (C4129, Sigma Aldrich), and S. griseus protease type XIV (P5147, Sigma Aldrich). The percent of protein digestibility was calculated using the following equation [14]:

$$
\mathrm{IPD}=210.464-18.103 \times(\mathrm{pH} \text { at } 10 \mathrm{~min} \text { digestion })
$$

\subsection{Bread Characterization}

\subsubsection{Color}

For each bread, crumb color was analyzed accordingly with Figuera-Cárdenas et al. [15] using a MiniScan XE Plus colorimeter (Hunter Lab, Virginia, United States, bidirectional illumintation $45^{\circ} / 0^{\circ}$, Illuminants D 65 and observer $2^{\circ}$ ).

Values reordered were: $\mathrm{L}^{*}$ (lightness), $\mathrm{a}^{*}$ (redness: green to red), and $\mathrm{b}^{*}$ (yellowness: blue to yellow). Calibration was carried out using a standard white tile manufactured by the provider. Results were the average of 10 measures of bread per formula measured one day post-baking.

\subsubsection{Specific Volume}

Regarding specific volume, bread were weighed after cooling for $1 \mathrm{~h}$, and their volume $\left(\mathrm{cm}^{3}\right)$ was determined by the millet displacement method. The specific volume $\left(\mathrm{cm}^{3} / \mathrm{g}\right)$ was calculated as loaf volume/bread weight [16].

\subsection{Sensorial Evaluation}

Sensory evaluation was undertaken on 1 st-day post-baking with 40 semi-trained panelists. Panelists were familiar with white bread. Written consent was obtained from each subject after explaining the procedure of them. Sensory evaluation was conducted in a laboratory with adequate light and space based on the methodology described by Millar et al. [17] with some modifications.

Briefly, samples were placed on white polystyrene plates labeled with random codes and presented to consumers in a randomized order. A $60 \mathrm{~s}$ time laps were employed between each sensory palate to reduce sensory fatigue, and potable water was used as a palate cleanser between tastings. Each panelist assessed all three samples of each bread with legume and was asked to indicate his or her opinion about odor, texture, color, and flavor of the products, using a 5-point hedonic scale (from 5: like extremely to 1: dislike extremely). The samples could be re-tasted as often as desired.

\subsection{Statistical Analysis}

Statistical differences were assessed using one-way ANOVA followed by Tukey's multiple comparison test at a significance level of 0.05 . The statistical analysis was performed using the JMP 5.0.1 software (SAS, Cary, NC, USA).

\section{Results and Discussion}

\subsection{Beans and Bread Chemical Composition}

Table 2 presents the proximal composition of $\mathrm{BB}$ flour, $\mathrm{AB}$ flour, and bread elaborated with flour mixes (wheat flour and $\mathrm{BB}$ or $\mathrm{AB}$ ). Ayocote bean and black bean reported different protein content, with ayocote depicting the higher percentage (23.94\%). Other authors have reported a range of $19.5-31.0 \%$ of crude protein in beans [18]. AlvaradoLópez et al. [6] considerate ayocote as a promising source of protein. Protein content in bread increased with the addition of the legumes in a range of $15-34 \%$. In general, legume proteins are rich in lysine and threonine [19]; both essential amino acids are limited in durum wheat [20]. Ash content for bread added with both legumes was higher, indicating an increment in mineral content, as Hoehnel et al. [4] presented previously, legumes flours presented higher mineral content. The same pattern was reported for crude fiber. Both legumes improved the chemical composition of bread, demonstrating the possibility of legumes utilization to increase the nutritional quality of bread in terms of protein, fiber, and ash content, especially in bread added with more AB and BB flour levels, but this 
impact in sensorial and quality attributes as presented below. Finally, energy value was evaluated, with an increment in this parameter because beans have high energy values. This variable in bread with $\mathrm{AB}$ and $\mathrm{BB}$ increased mainly by protein coming from $\mathrm{AB}$ and $B B$. Percentage of calories provided from protein presented a range of 16.33-18.94 in breads added with at $\mathrm{AB}$ and $\mathrm{BB}$ flours, in contrast with the control where kilocalories provided from protein were $14.50 \%$. A similar pattern was presented for fiber, where the percentage of kilocalories coming from this nutrient increased from 0.32 to $0.39-1.22 \%$. In contrast, kilocalories coming from carbohydrates and fat decreased in bread when wheat flour was replaced with $\mathrm{AB}$ and $\mathrm{BB}$. The contribution of kilocalories from carbohydrates decreased from 60.22 in control bread to a range of 53.68 to $58.38 \%$ in breads with $\mathrm{AB}$ and $\mathrm{BB} \%$. Regarding energy, similar values for breads were identified previously by Ahmad et al. [21]. They concluded that protein and fiber kilocalories were higher in cumin and caraway seeds. Additionally, the difference in fat is because seed presented higher fat content than beans studied in this project.

Table 2. Proximate composition of black bean (BB), ayocote bean (AB), control bread and breads with 10,20 and $30 \%$ of wheat flour substitution with $\mathrm{BB}$ and $\mathrm{AB}$ in dry weight basis *.

\begin{tabular}{|c|c|c|c|c|c|c|}
\hline Samples & Crude Protein (\%) & Ash (\%) & Crude Fiber (\%) & Crude Fat $(\%)$ & Carbohydrates (\%) & $\begin{array}{l}\text { Energy Value } \\
\text { (Kcal/100 g) }\end{array}$ \\
\hline $\begin{array}{l}\text { Black bean (Phaseolus } \\
\text { vulgaris L.) flour }\end{array}$ & $21.06 \pm 0.13$ & $4.20 \pm 0.04$ & $3.06 \pm 0.07$ & $1.68 \pm 0.26$ & $59.43 \pm 1.22$ & $342.20 \pm 0.12$ \\
\hline $\begin{array}{l}\text { Ayocote bean (Phaseolus } \\
\text { coccineus L.) flour }\end{array}$ & $23.94 \pm 0.36$ & $3.70 \pm 0.13$ & $5.21 \pm 0.53$ & $1.31 \pm 0.02$ & $56.36 \pm 1.28$ & $343.41 \pm 0.34$ \\
\hline Control bread & $12.60 \pm 0.06 \mathrm{~d}$ & $0.19 \pm 0.01 c$ & $0.57 \pm 0.09 c$ & $9.63 \pm 0.31 b$ & $52.31 \pm 1.43 \mathrm{a}$ & $347.45 \pm 0.05 \mathrm{f}$ \\
\hline \multicolumn{7}{|c|}{ Bread with black bean (Phaseolus vulgaris L.) } \\
\hline $10 \%$ & $14.67 \pm 0.12 c$ & $0.23 \pm 0.03 c$ & $0.71 \pm 0.12 \mathrm{c}$ & $11.53 \pm 0.35 \mathrm{a}$ & $48.86 \pm 1.55 \mathrm{ab}$ & $359.31 \pm 0.10 c$ \\
\hline $20 \%$ & $15.23 \pm 0.09 \mathrm{bc}$ & $0.27 \pm 0.02 b$ & $0.98 \pm 0.17 \mathrm{c}$ & $11.67 \pm 0.37 \mathrm{a}$ & $50.70 \pm 1.31 \mathrm{ab}$ & $370.71 \pm 0.07 \mathrm{~b}$ \\
\hline $30 \%$ & $15.72 \pm 0.06 \mathrm{ab}$ & $0.34 \pm 0.07 \mathrm{a}$ & $1.24 \pm 0.13 \mathrm{~b}$ & $11.90 \pm 0.18 \mathrm{a}$ & $49.98 \pm 0.35 \mathrm{ab}$ & $372.38 \pm 0.09 \mathrm{a}$ \\
\hline \multicolumn{7}{|c|}{ Bread with ayocote bean (Phaseolus coccineus L.) } \\
\hline $10 \%$ & $14.84 \pm 0.10 \mathrm{bc}$ & $0.21 \pm 0.04 \mathrm{c}$ & $1.61 \pm 0.22 b$ & $8.62 \pm 0.45 c$ & $50.32 \pm 1.18 \mathrm{ab}$ & $341.44 \pm 0.35 \mathrm{~g}$ \\
\hline $20 \%$ & $16.33 \pm 0.10 \mathrm{a}$ & $0.27 \pm 0.01 \mathrm{~b}$ & $2.03 \pm 0.45 \mathrm{a}$ & $10.32 \pm 0.18 b$ & $48.20 \pm 1.79 \mathrm{~b}$ & $355.06 \pm 0.08 \mathrm{e}$ \\
\hline $30 \%$ & $16.88 \pm 0.09 \mathrm{a}$ & $0.39 \pm 0.04 \mathrm{a}$ & $2.18 \pm 0.28 a$ & $9.63 \pm 0.29 b$ & $49.47 \pm 1.63 \mathrm{ab}$ & $356.43 \pm 0.09 \mathrm{~d}$ \\
\hline
\end{tabular}

* The values represent the mean \pm standard deviation. Values with different letters in the same column for each sample are significantly different $(p \leq 0.05)$.

\subsection{Thermal Properties of Bread Incorporated with Black Bean and Ayocote Bean}

Results for thermal properties: retrogradation, gelatinization, and amylose lipid complexes + protein digestibility of black bean, ayocote bean, and bread can be observed in Tables 3 and 4. Differences in thermal profiles were associated with variations in chemical composition and quality protein fractions. Retrogradation transition temperatures $\operatorname{To}_{\mathrm{R}}$, $\mathrm{Tp}_{\mathrm{R}}$, and $\mathrm{Tf}_{\mathrm{R}}$ and enthalpy for control bread and bread with 10 and $20 \%$ of black bean were $46.27{ }^{\circ} \mathrm{C}, 54.23{ }^{\circ} \mathrm{C}, 63.62{ }^{\circ} \mathrm{C}$, and $0.25 \mathrm{~J} / \mathrm{g}$ (in average) Xie et al. [22] declared that amylopectin melting peak temperatures were $60-70{ }^{\circ} \mathrm{C}$ for bread stored at high temperature. Some samples did not present retrogradation endotherm because those bread had low staling time. Only in control and samples with 10 and 20\% of BB was this endotherm observed; those differences are governed because in those samples, amylopectin presented a high availability to reassociate in an ordered structure because amylopectin formed a smaller number of links with protein and lipids. Addition of $30 \%$ black bean and ayocote bean to bread limited the bread retrogradation. Abdel-Aal and Hucl. [22] indicated that protein slowed down the bread staling process. Additionally, an increase in fat content in bread increases amylose lipid complexes (Table 4), associated with reducing the retrogradation process [23]. Gelatinization temperatures $\left(\mathrm{To}_{\mathrm{g}}, \mathrm{Tp}_{\mathrm{g}}\right.$, and $\left.\mathrm{Tf}_{\mathrm{g}}\right)$ for black bean and ayocote bean on average were $67.76^{\circ} \mathrm{C}, 79.23^{\circ} \mathrm{C}$, and $88.63{ }^{\circ} \mathrm{C}$; similar values were identified previously by Ahmad et al. [21] in black bean. Also, gelatinization endotherm presented differences among control bread and samples with beans. Control presented a higher endotherm than the other samples. Gelatinization was higher in control bread, 
followed by bread with lower ayocote and black bean concentration; endotherm for control was undetectable because starch was completely gelatinized. Lower gelatinization temperatures are correlated with lower starch digestibility. In the third thermal transition (Table 4), the temperature range observed for raw beans were at $94-104.6{ }^{\circ} \mathrm{C}$ (average), this is similar to data reported by Santiago-Ramos et al. [23]. Some authors have reported that this endotherm corresponds to the melting of amylose lipid complexes, and denaturalization of heat resistant protein fractions. For breads added with ayocote and black bean, this endotherm presented higher enthalpy values, this could be attributed to the addition of ayocote and black bean, indicating that those breads have more protein, protein content and $\Delta \mathrm{H}$ of amylose lipid and protein denaturalization presented a correlation $(\mathrm{r})$ of 0.45 , also these breads also presented more amylose lipid complexes. Protein and fat were increased by $\mathrm{BB}$ and $\mathrm{AB}$ addition, and the beans impacted chemical bread composition, also when more fat is added if amylose is not saturated, it can form amylose lipid complexes, which are classified as part of the resistant starch (Type 5).

Table 3. Retrogradation and gelatinization properties of black bean (BB), ayocote bean (AB), and breads by DSC analysis *

\begin{tabular}{|c|c|c|c|c|c|c|c|c|}
\hline \multirow[b]{2}{*}{ Sample } & \multicolumn{4}{|c|}{ Melting of Retrograded Starch } & \multicolumn{4}{|c|}{ Starch Gelatinization } \\
\hline & ToR $\left({ }^{\circ} \mathrm{C}\right)$ & $\operatorname{TpR}\left({ }^{\circ} \mathrm{C}\right)$ & $\operatorname{TfR}\left({ }^{\circ} \mathrm{C}\right)$ & $\Delta \mathrm{H}(\mathrm{J} / \mathrm{g})$ & To $g\left({ }^{\circ} \mathrm{C}\right)$ & $\operatorname{Tpg}\left({ }^{\circ} \mathrm{C}\right)$ & $\operatorname{Tf} g\left({ }^{\circ} \mathrm{C}\right)$ & $\Delta \mathrm{H}(\mathrm{J} / \mathrm{g})$ \\
\hline Black bean flour & & & & & 73.44 & 85.80 & 93.48 & 3.15 \\
\hline $\begin{array}{l}\text { Ayocote } \\
\text { bean flour }\end{array}$ & & & & & 62.08 & 72.66 & 83.78 & 4.49 \\
\hline Control bread & $45.83 \pm 1.87 \mathrm{a}$ & $55.32 \pm 0.35 \mathrm{a}$ & $65.65 \pm 0.47 \mathrm{a}$ & $0.26 \pm 0.08 \mathrm{a}$ & & & & \\
\hline \multicolumn{9}{|c|}{ Bread with black bean (Phaseolus vulgaris L.) } \\
\hline $10 \%$ & $47.67 \pm 2.13 \mathrm{a}$ & $53.55 \pm 0.10 \mathrm{~b}$ & $62.25 \pm 0.21 b$ & $0.21 \pm 0.05 \mathrm{a}$ & $70.93 \pm 0.28 \mathrm{bc}$ & $80.03 \pm 0.17 \mathrm{~b}$ & $86.13 \pm 0.22 \mathrm{c}$ & $0.14 \pm 0.01 \mathrm{c}$ \\
\hline $20 \%$ & $45.33 \pm 0.48 \mathrm{a}$ & $53.83 \pm 0.35 b$ & $62.96 \pm 0.48 b$ & $0.28 \pm 0.05 \mathrm{a}$ & $67.40 \pm 0.39 \mathrm{e}$ & $81.63 \pm 0.49 \mathrm{a}$ & $86.46 \pm 0.57 \mathrm{c}$ & $0.27 \pm 0.05 b c$ \\
\hline $30 \%$ & & & & & $73.10 \pm 0.54 \mathrm{a}$ & $79.83 \pm 0.12 b$ & $84.51 \pm 0.34 \mathrm{~d}$ & $0.56 \pm 0.08 \mathrm{a}$ \\
\hline \multicolumn{9}{|c|}{ Bread with ayocote bean (Phaseolus coccineus L.) } \\
\hline $10 \%$ & & & & & $66.72 \pm 0.48 \mathrm{~d}$ & $74.50 \pm 0.12 \mathrm{c}$ & $89.12 \pm 0.47 \mathrm{~b}$ & $0.18 \pm 0.04 \mathrm{c}$ \\
\hline $20 \%$ & & & & & $72.44 \pm 0.44 \mathrm{ab}$ & $73.18 \pm 0.23 \mathrm{~d}$ & $90.12 \pm 0.34 \mathrm{ab}$ & $0.22 \pm 0.10$ \\
\hline $30 \%$ & & & & & $70.35 \pm 1.01 \mathrm{c}$ & $74.25 \pm 0.18 c$ & $90.17 \pm 0.12 \mathrm{a}$ & $0.44 \pm 0.05 \mathrm{ab}$ \\
\hline
\end{tabular}

* The values represent the mean \pm standard deviation. Values with different letters in the same column for each sample are significantly different $(p \leq 0.05)$. ToR: onset retrogradation temperature; TpR: peak retrogradation temperature; TfR: Final retrogradation temperature; AH: enthalpy; Tog: onset gelatinization temperature; Tpg: peak gelatinization temperature; Tfg: final gelatinization temperature.

Table 4. Amylose lipid and protein denaturalization of black bean, ayocote bean, and breads by DSC analysis *

\begin{tabular}{|c|c|c|c|c|}
\hline \multicolumn{5}{|c|}{ Melting of Amylose-Lipid Complexes + Protein Denaturalization } \\
\hline Sample & To AMLC+PD $\left({ }^{\circ} \mathrm{C}\right)$ & Tp AMLC+PD $\left({ }^{\circ} \mathrm{C}\right)$ & $\mathrm{Tf}_{\mathrm{AMLC}+\mathrm{PD}}\left({ }^{\circ} \mathrm{C}\right)$ & $\Delta \mathbf{H}(\mathrm{J} / \mathrm{g})$ \\
\hline Black bean flour & $97.70 \pm 0.34$ & $101.95 \pm 0.54$ & $106.17 \pm 0.32$ & $1.65 \pm 0.09$ \\
\hline Ayocote bean flour & $90.21 \pm 0.26$ & $96.47 \pm 0.41$ & $103.02 \pm 0.17$ & $1.71 \pm 0.06$ \\
\hline Control bean & $100.05 \pm 0.14 b$ & $106.48 \pm 0.47 \mathrm{a}$ & $113.20 \pm 0.20 \mathrm{a}$ & $0.78 \pm 0.04 \mathrm{~d}$ \\
\hline \multicolumn{5}{|c|}{ Bread with black bean (Phaseolus vulgaris L.) } \\
\hline $10 \%$ & $89.28 \pm 0.27 \mathrm{e}$ & $105.57 \pm 0.45 \mathrm{a}$ & $109.55 \pm 0.55 \mathrm{bc}$ & $0.68 \pm 0.07 \mathrm{~d}$ \\
\hline $20 \%$ & $88.25 \pm 0.25 \mathrm{f}$ & $102.43 \pm 0.60 \mathrm{~b}$ & $109.83 \pm 0.63 b c$ & $0.97 \pm 0.06 \mathrm{~d}$ \\
\hline $30 \%$ & $101.97 \pm 0.50 \mathrm{a}$ & $106.47 \pm 0.27 \mathrm{a}$ & $109.90 \pm 0.49 b$ & $1.38 \pm 0.08 c$ \\
\hline \multicolumn{5}{|c|}{ Bread with ayocote bean (Phaseolus coccineus L.) } \\
\hline $10 \%$ & $94.34 \pm 0.56 c$ & $102.46 \pm 0.26 \mathrm{~b}$ & $108.12 \pm 0.12 \mathrm{~cd}$ & $1.48 \pm 0.19 c$ \\
\hline $20 \%$ & $95.14 \pm 0.34 c$ & $103.13 \pm 0.33 b$ & $108.63 \pm 0.63 \mathrm{bcd}$ & $2.08 \pm 0.08 \mathrm{~b}$ \\
\hline $30 \%$ & $93.17 \pm 0.27 \mathrm{~d}$ & $103.59 \pm 0.97 b$ & $106.97 \pm 1.14 \mathrm{~d}$ & $2.50 \pm 0.18 \mathrm{a}$ \\
\hline
\end{tabular}

* The values represent the mean \pm standard deviation. Values with different letters in the same column for each sample are significantly different $(p \leq 0.05)$. To $\mathrm{AMLC}_{\mathrm{PD}}$ : onset temperature of amylose lipid complexes + protein denaturalization; $\mathrm{Tp} \mathrm{AMLC}_{\mathrm{PD}}$ : peak temperature of amylose lipid complexes + protein denaturalization; $\mathrm{Tf}_{\mathrm{AMLC}+\mathrm{PD}}$ : final temperature of of amylose lipid complexes + protein denaturalization. 


\subsection{In Vitro Protein Digestibility}

As previously described, in vitro protein digestibility was determined with a multienzymatic method. Protein digestibility is defined as the ability of an organism to hydrolyze, absorb, and use amino acids linked by peptide bonds [24]. Figure 1 shows the results of in vitro protein digestibility of control bread, bread added with ayocote bean and black bean, and raw beans.

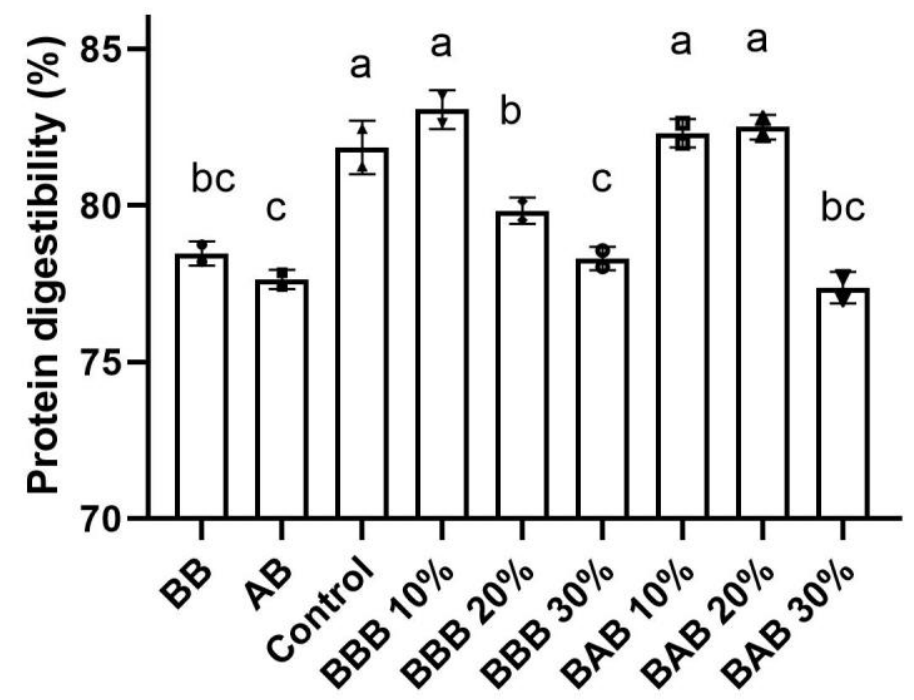

Figure 1. Protein digestibility of black bean, ayocote bean and breads. BB: Black bean flour; AB: Ayacote bean flour; BBB Bread with black bean; BAB: Bread with ayacote beans.

Raw beans and bread with $30 \%$ of wheat flour substitution presented lower protein digestibility than bread with 10 and $20 \%$ of substitution. Breadmaking is a complex process that involves various steps, [25] investigated the protein digestibility changes during breadmaking using gluten-containing and gluten-free flours. Protein digestibility is shown to increase during fermentation/proofing. Additionally, [26] argue that food processing techniques have been demonstrating to improve the nutritional quality of plant proteins by eliminating or inactivating the compounds that can be diminished in vitro protein digestibility. For this reason, it seems that protein digestibility was incremented by inactivation of antinutritional compounds and fermentation, in samples with 10 and 20\% of $\mathrm{AB}$ and $10 \%$ of $\mathrm{BB}$ have similar IPD than control. However, when concentrations are greater than those percentages, there is a downgrade in IPD, as [25] identified, when there is an increase in fiber content, there is a reduction in IPD, IPD and fiber content presented a negative correlation $(\mathrm{r}=-0.6 ; p \leq 0.05)$. Samples with $\mathrm{AB}$ presented a reduction in higher concentrations $(>20 \%$ ) because $\mathrm{AB}$ has higher fiber content. This behavior has been reported previously by other authors, more enzyme accessibility to the protein could be improved by more $\mathrm{AB}$ and $\mathrm{BB}$ processing to gain more protein enzyme access and increase IPD; however, it plays a key role in the use of non-thermal processes to get a better nutritional profile without degrading nutraceutical and vitamins.

\subsection{Bread Characterization}

\subsubsection{Color}

Color is a key parameter that is related to consumer acceptance and is a quality parameter for bread. Additionally, beans color is associated with the existence of phenolic compounds, such as flavonol glycosides, anthocyanins and condensed tannins, those components are considered health-promoting compounds, phenolic compounds contribute to antioxidative activities, removing free radicals, chelating metal catalysis, activating antioxidant enzymes and inhibited oxidases [6]. In this study, bread with different formulations were evaluated for color. Bread denoted color differences, with values were 
summarized in Table 5. The parameter $L^{*}$ corresponds to the lightness of the bread, a trait that decreased gradually with the addition of ayocote bean and black bean, mainly by coat color of both; however, as can be observed in Table 5 , black bean influences more in this parameter compared with ayocote bean flour with values ranging from 54.56 to 58.57 and 62.26 to 63.55 , respectively. As other authors have reported, bread $L^{*}$ values between 51-100 indicate light products [27], as depicted in Table 5. However, the influence of BB and $A B$ in $\mathrm{L}$ is clear as the $\mathrm{L}$ value decreased when legume flour increases.

Table 5. Color and sensory evaluation of breads *

\begin{tabular}{|c|c|c|c|c|c|c|c|c|}
\hline \multirow{2}{*}{ Samples } & \multirow{2}{*}{$\%$} & \multicolumn{3}{|c|}{ Color } & \multicolumn{3}{|c|}{ Sensorial Analysis ${ }^{b}$} & \multirow[b]{2}{*}{ Color } \\
\hline & & $\mathbf{L}^{*}$ & $\mathbf{A}^{*}$ & $\mathbf{B}^{*}$ & Odor & Flavor & Texture & \\
\hline Control & & $65.25 \pm 0.18 \mathrm{a}$ & $5.07 \pm 0.07 \mathrm{a}$ & $15.32 \pm 0.07 \mathrm{a}$ & $4.25 \pm 0.48 \mathrm{a}$ & $4.15 \pm 0.48 \mathrm{a}$ & $4.15 \pm 0.63 \mathrm{a}$ & $3.85 \pm 0.81 \mathrm{a}$ \\
\hline \multirow{3}{*}{$\begin{array}{l}\text { Black bean (Phaseolus } \\
\text { vulgaris L.) breads }\end{array}$} & 10 & $58.57 \pm 0.10 \mathrm{~d}$ & $2.80 \pm 0.05 \mathrm{~d}$ & $10.70 \pm 0.12 \mathrm{e}$ & $3.80 \pm 0.69 \mathrm{ab}$ & $3.80 \pm 0.69 \mathrm{a}$ & $3.75 \pm 0.71 \mathrm{a}$ & $3.85 \pm 0.81 \mathrm{ab}$ \\
\hline & 20 & $58.51 \pm 0.41 \mathrm{~d}$ & $1.95 \pm 0.08 \mathrm{e}$ & $8.83 \pm 0.14 \mathrm{f}$ & $2.95 \pm 0.94 \mathrm{bc}$ & $2.90 \pm 0.85 b$ & $2.50 \pm 0.88 \mathrm{~b}$ & $2.90 \pm 0.78 \mathrm{~cd}$ \\
\hline & 30 & $54.56 \pm 0.51 \mathrm{e}$ & $1.63 \pm 0.08 \mathrm{f}$ & $6.98 \pm 0.16 \mathrm{~g}$ & $1.85 \pm 1.08 \mathrm{~d}$ & $1.95 \pm 0.88 \mathrm{c}$ & $2.30 \pm 0.86 b$ & $2.05 \pm 0.75 \mathrm{e}$ \\
\hline \multirow{3}{*}{$\begin{array}{l}\text { Ayocote (Phaseolus } \\
\text { coccineus L.) breads }\end{array}$} & 10 & $63.55 \pm 0.30 \mathrm{~b}$ & $4.72 \pm 0.15 b$ & $14.55 \pm 0.24 b$ & $3.95 \pm 0.68 \mathrm{a}$ & $3.79 \pm 1.05 \mathrm{a}$ & $3.55 \pm 0.71 \mathrm{a}$ & $3.80 \pm 0.73 \mathrm{a}$ \\
\hline & 20 & $62.51 \pm 0.28 c$ & $4.12 \pm 0.01 \mathrm{c}$ & $13.10 \pm 0.09 c$ & $2.20 \pm 1.00 \mathrm{~cd}$ & $2.45 \pm 0.75 b c$ & $2.35 \pm 0.67 b$ & $3.00 \pm 0.65 \mathrm{~cd}$ \\
\hline & 30 & $62.26 \pm 0.46 c$ & $3.90 \pm 0.05 c$ & $12.43 \pm 0.10 \mathrm{~d}$ & $1.80 \pm 1.00 \mathrm{~d}$ & $2.10 \pm 0.78 c$ & $2.20 \pm 0.85 b$ & $2.55 \pm 0.51 \mathrm{de}$ \\
\hline
\end{tabular}

* The values represent the mean \pm standard deviation. Values with different letters in the same column for each sample are significantly different $(p \leq 0.05) .{ }^{\mathrm{b}}$ Evaluated on a scale of 1 to 5 , where 5 was the maximum value.

Additionally, positive values for $\mathrm{a}^{*}$ and $\mathrm{b}^{*}$ indicate redness and yellowness, respectively [27]. Control bread presented $a b^{*}$ value of 15.32; in contrast, bread added with $A B$ presented a range from 12.43 to 14.55 , and bread with $\mathrm{BB}$ showed a range from 6.98 to 10.7. Lower $b^{*}$ values were observed in bread with major wheat flour substitution because yellowness is given by wheat flour. Values obtained for $\mathrm{a}^{*}$ parameter indicated that bread added with $\mathrm{AB}$ are more reds than other bread. Ayocote had a coat with more red pigments as anthocyanins. Hence, it can be concluded that BB and AB contribute to changing the color values of the final product.

\subsubsection{Specific Volume}

Specific volume is a quality parameter in bread. Bread with 10 and $20 \%$ of added $\mathrm{BB}$ presented no differences in specific volume compared with control; the same was true for $10 \%$ AB bread (Figure 2). However, when BB was used at $30 \%$ and AB above $20 \%$, it resulted in a significantly lower volume. The addition of black and ayocote bean decreased the gluten concentration in breads. This protein plays a crucial role in guaranteeing wheat's bakery quality and influences water absorption, cohesion, viscosity, extensibility, elasticity, resistance deformation, tolerance to kneading, ability to gas retention and dough strengthening properties [28,29]. Besides, those breads contain more fiber, as was observed in the chemical composition (Table 2), and according to [30], this addition contributes to gluten dilution in the food matrix. As explained before, the gluten protein forms a three-dimensional network that entraps carbon dioxide in bread and in the case of breads with high bean flour addition, the network was reduced, and less $\mathrm{CO}_{2}$ could be maintained decreasing volume. This can also influence the texture and softness of the bread.

\subsection{Sensorial Analysis}

Results of sensory evaluation of breads samples containing different beans levels are shown in Table 5. Four parameters (odor, texture, color, and flavor) were evaluated to determine the breads' acceptance. The first parameter evaluated was the odor, which is an essential sensorial parameter in organoleptic characteristics. According to data presented in Table 5 the panelist preferred control bread, it obtained 4.25 on a scale where 5 was the maximum, followed in acceptance for breads with 10\% with a 3.80 and 3.95 for black bean and ayocote addition, in contrast, an addition of $30 \%$ of both legumes caused the least acceptance (1.80 to 1.85), which can be related to the characteristic odor of $\mathrm{BB}$ and $\mathrm{AB}$, more detectable at this concentration. The taste had a similar pattern that smell; it seems 
that legumes used are detectable for panelists at a concentration above $20 \%$. For texture, panelists preferred control and breads at 10\%, followed by 20 and $30 \%$. Texture by sensorial analysis presented a negative correlation with fiber $(\mathrm{r}=-0.92$ and $\mathrm{r}=-0.98)$ and protein content $(r=-0.93$ and, they presented content and $r=-0.98)$ for breads with black bean and ayocote bean respectively. As defined before, the texture was influenced negatively by gluten dilution by other macromolecules added from beans, avoiding air retention and affecting softness. A similar pattern has been reported before by Ahmad et al. [21] and Hoehnel et al. [4]. It has been reported that although fiber has a positive nutritional effect, it can reduce the expansion of the gas cells leading to a lower volume of loaves and smaller porosity of the crumbs [2].

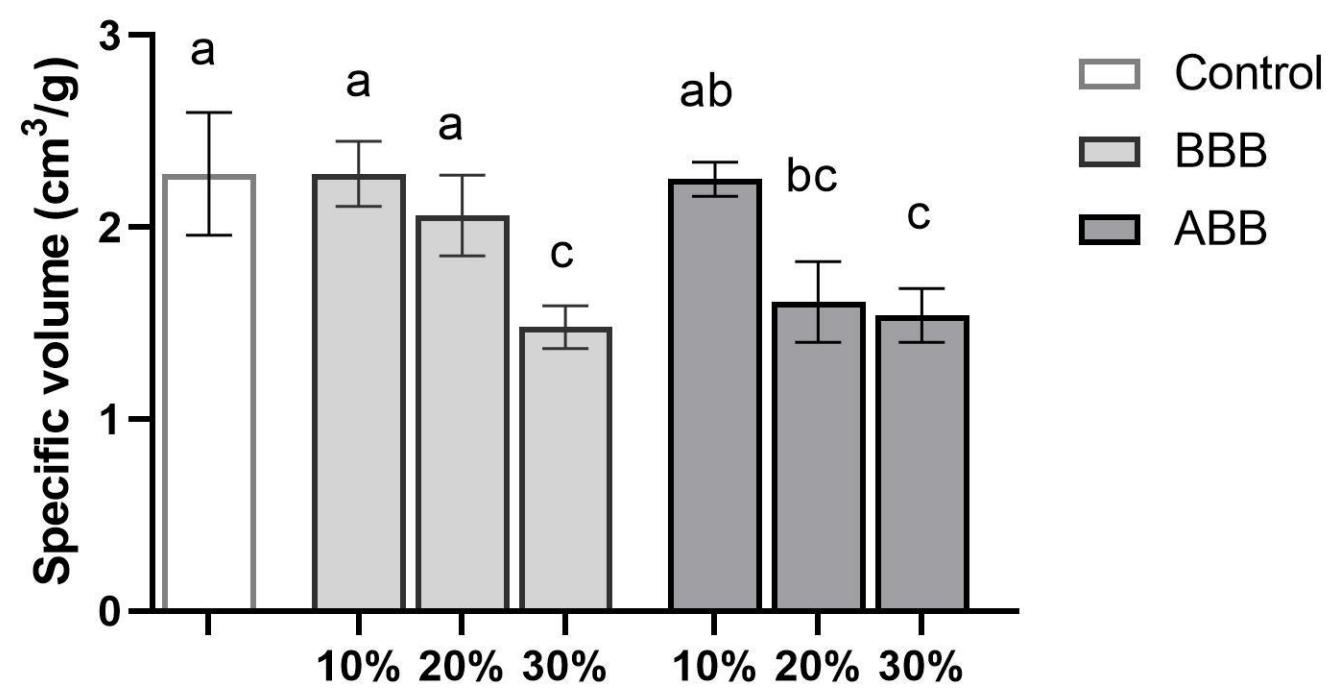

Figure 2. The volume of control bread and breads added with black bean and ayocote bean. BBB: Bread with black beans and ABB: Bread with ayacote beans.

Finally, panelists could detect color differences, like changes measured by a colorimeter. Moreover, as explained above, those color modifications are associated with pigments present in the bean coatings. Therefore, the sensorial analysis showed that it could substitute $10 \%$ black bean and ayocote bean without perceived changes in a sensorial panel. Other studies indicated that chestnut and coconut can be used at percentages up to $15 \%$ similar to the consumer acceptance level seen in this study [2].

\section{Conclusions}

Breads fortified with $\mathrm{BB}$ and $\mathrm{AB}$ offer people the option to improve the nutritional quality of their diet, specifically the protein content, fiber, and fat content, and is a good option for low-income people. Additionally, an ash increment also denoted a higher mineral content, however, mineral-specific analysis is needed to further evaluate this aspect. The energy content was higher for breads with bean flour addition, and most of this calorie increment came from protein, fiber, and fat. Moreover, those breads added with beans showed similar protein digestibility, except when used at levels higher than $20 \%$. Thermal analysis suggests that gelatinization temperature is reduced, and consequently, starch digestibility too. Finally, the addition of black bean and ayocote impacts some quality characteristics, as color and volume. Volume was affected when the substitution level was above $20 \%$. Regarding color, it changed in all breads with BB and AB; however, it does not influence panelist acceptance by sensory evaluation when the addition is below $20 \%$.

Author Contributions: Conceptualization, R.M.M.-M.; methodology, R.M.M.-M., C.C.-H., J.d.D.F.-C. and S.O.S.-S.; formal analysis, R.M.M.-M., C.C.-H., J.d.D.F.-C. and S.O.S.-S.; writing-original draft preparation, R.M.M.-M. and C.C.-H.; writing-review and editing, C.C.-H., J.d.D.F.-C. and S.O.S.-S. All authors have read and agreed to the published version of the manuscript. 
Funding: R.M.M.-M. received financial support from the for the publishing fees from Universidad Iberoamericana.

Institutional Review Board Statement: Sensorial evaluation was performed according with IFST (Institute of Food Science and technology) Guidelines for Ethical and Professional Practices for the Sensory Analysis of Foods.

Informed Consent Statement: Informed consent was obtained from all subjects involved in the study.

Data Availability Statement: The data presented in this study are available on request from the corresponding author.

Acknowledgments: Authors are grateful with Universidad Iberoamericana Ciudad de Mexico. And to Alondra Ramírez Hernández, Jose Juan Veles Medina and Rosa Selene Espiricueta Candelaria to their support for this work. Additional thanks are due the Centro de Agua para América Latina y el Caribe del Tecnológico de Monterrey.

Conflicts of Interest: The authors declare no conflict of interest.

\section{References}

1. Dewettinck, K.; van Bockstaele, F.; Kuhen, F.; Van de Walle, D.; Courtens, T.M.; Gellynck, X. Nutritional value of bread: Influence of processing, food interaction and consumer perception. J. Cereal Sci. 2008, 48, 243-257. [CrossRef]

2. Raczyk, M.; Kruszewski, M.; Michalowska, D. Effect of Coconut and Chestnut Flour Supplementations on Texture, Nutritional and Sensory Properties of Baked Wheat Based. Molecules 2021, 26, 4641. [CrossRef]

3. Krupa-Kozak, U.; Drabińska, N.; Baczek, N.; Šimková, K.; Starowicz, M.; Jeliński, T. Application of broccoli leaf powder in gluten-free bread: An innovative approach to improve its bioactive potential and technological quality. Foods 2021, 10, 819. [CrossRef]

4. Hoehnel, A.; Axel, C.; Bez, J.; Arendt, E.K.; Zannini, E. Comparative analysis of plant-based high-protein ingredients and their impact on quality of high-protein bread. J.Cereal Sci. 2019, 89, 102816. [CrossRef]

5. Ruíz-Salazar, R.; Mayek-Pérez, N.; Vargas-Vázquez, M.L.; Hernández-Delgado, S.; Muruaga-Martínez, J. Análisis de la estructura poblacional del frijol Ayocote (Phaseolus coccineus L.) mediane AFLP. Polibotánica 2019, 46, 13-24. [CrossRef]

6. Alvarado-López, A.N.; Gómez-Oliván, L.M.; Heredia, J.B.; Baeza-Jiménez, R.; Garcia-Galindo, H.S.; Lopez-Martinez, L.X. Nutritional and bioactive characteristics of Ayocote bean (Phaseolus coccienus L.): An underutilized legume harvested in Mexico. CYTA-J. Food 2019, 17, 199-206. [CrossRef]

7. Available online: http://www.fao.org/documents/card/en/c/f961bcd6-85db-405e-af70-3ed044f1b1d7/ (accessed on 29 August 2021).

8. Gepts, P. Phaseolus vulgaris (Beans). In Encyclopedia of Genetics; Academic Press: Cambridge, MA, USA, $2001 ;$ pp. 1444-1445.

9. Brummer, Y.; Kaviani, M.; Tosh, S.M. Structural and functional characteristics of dietary fibre in beans, lentils, peas and chickpeas. Food Res. Int. 2015, 67, 117-125. [CrossRef]

10. Rizkalla, S.W.; Bellisle, F.; Slama, G. Health benefits of low glycaemic index foods, such as pulses, in diabetic patients and healthy individuals. Br. J. Nutr. 2002, 88, 255-262. [CrossRef]

11. De la Rosa-Millán, J.; Heredia-Olea, E.; Perez-Carrillo, E.; Guajardo-Flores, D.; Serna-Saldívar, S.R.O. Effect of decortication, germination and extrusion on physicochemical and in vitro protein and starch digestion characteristics of black beans (Phaseolus vulgaris L.). LWT 2019, 102, 330-337. [CrossRef]

12. Yeh, L.T.; Charles, A.L.; Ho, C.T.; Huang, T.C. A novel bread making process using salt-stressed Baker's yeast. J. Food Sci. 2009, 74, S399-S4002. [CrossRef]

13. Santiago-Ramos, D.; de Figueroa-Cárdenas, J.D.; Véles-Medina, J.J.; Mariscal-Moreno, R.M. Changes in the thermal and structural properties of maize starch during nixtamalization and tortilla-making processes as affected by grain hardness. J. Cereal Sci. 2017, 74, 72-78. [CrossRef]

14. Hsu, H.W.; Vavak, D.L.; Satterlee, L.D.; Miller, G.A. A Multienzyme Technique for Estimating Protein Digestibility. J. Food Sci. 1977, 42, 1269-1273. [CrossRef]

15. Figueroa Cárdenas, J.D.; Godinez, M.G.A.; Méndez, N.L.V.; Guzmán, A.L.; Acosta, L.M.F.; González-Hernández, J. Fortificacion y evaluacion de tortillas de nixtamal. Arch. Latinoam. Nutr. 2001, 51, 293-302.

16. Tomic, J.; Torbica, A.; Popovic, L.; Rakita, S.; Zivancev, D. Breadmaking potential and proteolytic activity of wheat varieties from two production years with different climate conditions. Food Feed Res. 2015, 42, 83-90. [CrossRef]

17. Millar, K.A.; Barry-Ryan, C.; Burke, R.; Hussey, K.; McCarthy, S.; Gallagher, E. Effect of pulse flours on the physiochemical characteristics and sensory acceptance of baked crackers. Int. J. Food Sci. Technol. 2017, 52, 1155-1163. [CrossRef]

18. Carbas, B.; Machado, N.; Oppolzer, D.; Ferreira, L.; Brites, C.; Rosa, E.A.S.; Barros, A.I.R.N.A. Comparison of near-infrared (NIR) and mid-infrared (MIR) spectroscopy for the determination of nutritional and antinutritional parameters in common beans. Food Chem. 2020, 306, 125509. [CrossRef] [PubMed] 
19. Alonso, R.; Orúe, E.; Zabalza, M.J.; Grant, G.; Marzo, F. Effect of extrusion cooking on structure and functional properties of pea and kidney bean proteins. J. Sci. Food Agric. 2000, 80, 397-403. [CrossRef]

20. Abdel-Aal, E.S.M.; Hucl, P. Amino acid composition and in vitro protein digestibility of selected ancient wheats and their end products. J. Food Compos. Anal. 2002, 15, 737-747. [CrossRef]

21. Ahmad, B.S.; Talou, T.; Straumite, E.; Sabovics, M.; Kruma, Z.; Saad, Z.; Hijazi, A.; Mera, O. Protein bread fortification with cumin and caraway seeds and by-product flour. Foods 2018, 7, 28. [CrossRef]

22. Xie, F.; Dowell, E.; Sun, X.S. Using Visible and Near-Infrared Reflectance Spectroscopy and Differential Scanning Calorimetry to Study Starch, Protein, and Temperature Effects on Bread Staling. Cereal Chem. 2004, 81, 249-254. [CrossRef]

23. Santiago-Ramos, D.; Figueroa-Cárdenas, J.D.; Véles-Medina, J.J.; Salazar, R. Physicochemical properties of nixtamalized black bean (Phaseolus vulgaris L.) flours. Food Chem. 2017, 240, 456-462. [CrossRef]

24. De Jongh, H.H.J.; Broerse, K. Application Potential of Food Protein Modification. In Advances in Chemical Engineering, 1st ed.; Nawaz, Naveed, S., Eds.; In TEch: London, UK, 2012; Volume 1, p. 584.

25. Wu, T.; Taylor, C.; Nebl, T.; Ng, K.; Bennett, L.E. Effects of chemicpp. al composition and baking on in vitro digestibility of proteins in breads made from selected gluten-containing and gluten-free flours. Food Chem. 2017, 233, 514-524. [CrossRef] [PubMed]

26. Gomes Almeida Sá, C.B.; Franco, M.Y.M.; Mattar, B.A.C. Food processing for the improvement of plant proteins digestibility. Crit. Rev. Food Sci. Nutr. 2020, 60, 3367-3386. [CrossRef]

27. Lafarga, T.; Álvarez, C.; Bobo, G.; Aguiló-Aguayo, I. Characterization of functional properties of proteins from Ganxet beans (Phaseolus vulgaris L. var. Ganxet) isolated using an ultrasound-assisted methodology. LWT 2018, 98, 106-112. [CrossRef]

28. Lazaridou, A.; Duta, D.; Papageorgiou, M.; Belc, N.; Biliaderis, C.G. Effects of hydrocolloids on dough rheology and bread quality parameters in gluten-free formulations. J. Food Eng. 2007, 79, 1033-1047. [CrossRef]

29. Wieser, H. Chemistry of gluten proteins. Food Microbiol. 2007, 24, 115-119. [CrossRef] [PubMed]

30. Martínez, M.M.; Díaz, Á.; Gómez, M. Effect of different microstructural features of soluble and insoluble fibres on gluten-free dough rheology and bread-making. J. Food Eng. 2014, 142, 49-56. [CrossRef] 